\title{
An Analysis on the Relationship between General Circulation and Climatic Fluctuation (Part 2)
}

\author{
- Specified Circulation ( $\mathrm{B}_{2}$ Type) and Further Discussion -
}

\author{
by Iwao Tsuchiya \\ Japan Meteorological Agency, Tokyo \\ (Manuscript received 20 May 1964)
}

\begin{abstract}
Thirty $\mathrm{B}_{2}$ type circulations (a blocking type pattern characterized by clear stationary troughs were proposed in the previous paper (Tsuchiya, 1963)) are selected at a certain criterion from the data of thirteen winter seasons for December 1944-February 1957. Then their climatic features are examined using daily meteorological data at nearly 100 stations of the middle latitudes in Northern Hemisphere. And we found out that there are clear temperature and precipitation anomalies over the eastern North America, the western Europe and the vicinity of Japan. This anomaly pattern resembles the continental glacier distribution during Pleistocene period.

Milankovitch presented a theory that seasonal and latitudinal secular variation of insolation computed from the earth's orbital movement as a planet explains the glacial growth. In connection with it, this paper describes the fact that the variation of insolation is favourable for causing the $B_{2}$ type pattern in general circulation in winter. It is considered that Milankovitch's hypothesis is reasonable in the light of the modern theory and the observed fact on general circulation of the atmosphere.

Finally, as an example of the process of the $\mathrm{B}_{2}$ type circulation, discussion is made on the abnormal worldwide cold wave observed in the winter of $1962 / 63$.
\end{abstract}

\section{Introduction}

Although we have very little knowledge about the real process of climatic fluctuation and the related general circulation, it is still necessary and important to postulate a working hypothesis for explanation of the mechanism of climatic fluctuation.

It would be the opinion of many investigators that the cause of the climatic fluctuation can be found in the variation of the large scale atmospheric circulation. Since the climatic fluctuation is a process of redistribution of heat, kinetic energy, and etc., it may be reasonable to consider that the largescale atmospheric circulation give rise to the long period climatic fluctuation. For example, the intensity of European blocking anticyclone varies at 22-23 year cycle, and the position of the quasi-stationary European upper trough of meandering westeries and the associated weather and climate show such long-term variation (Flohn, $1961 \mathrm{a}, \mathrm{b}$ )

Many investigations have dealt with the general circulation to explain the mechanism of climatic fluctuation (Willet, 1949; Kraus, 1960 ; Lamb and Johnson, 1959, 1961 ; Flohn, 1961a; Tsuchiya, 1963). The purpose of this paper is to study which brings a glacial growth in global scale; an increasing zonal circulation or an increasing meridional circulation.

In the author's previous paper (Tsuchiya, 1963), he presented a working hypothesis that a specified circulation pattern of $\mathrm{B}_{2}$ type, which is one of blocking types and is caused by intensified meridional circulation, involves an essential mechanism for the climatic fluctuation. The author also pointed out the $\mathrm{B}_{2}$ type circulation in winter is a fundamental cause which brings the abnormal climate in global scale and further it could lead to the 
glacial stage if such circulation prevailed for a very long duration.

In this paper, the author intends to examine the relation between the $B_{2}$ type circulation pattern and daily pattern of temperature and precipitation, and to make further analysis of climatic fluctuation. He also shows that his working hypothesis is not only compatible with Milankovitch's theory, but also it develops the latter.

\section{2. $B_{2}$ type circulations during winter sea- sons of Dec. 1944-Feb. 1957}

An ideal model of the $B_{2}$ type circulation is constructed from the data of January 1945, where this type of circulation dominated for two-thirds of the month. The pattern is shown in Fig. 1, which is taken from Fig. 4 in the author's previous paper (1963).

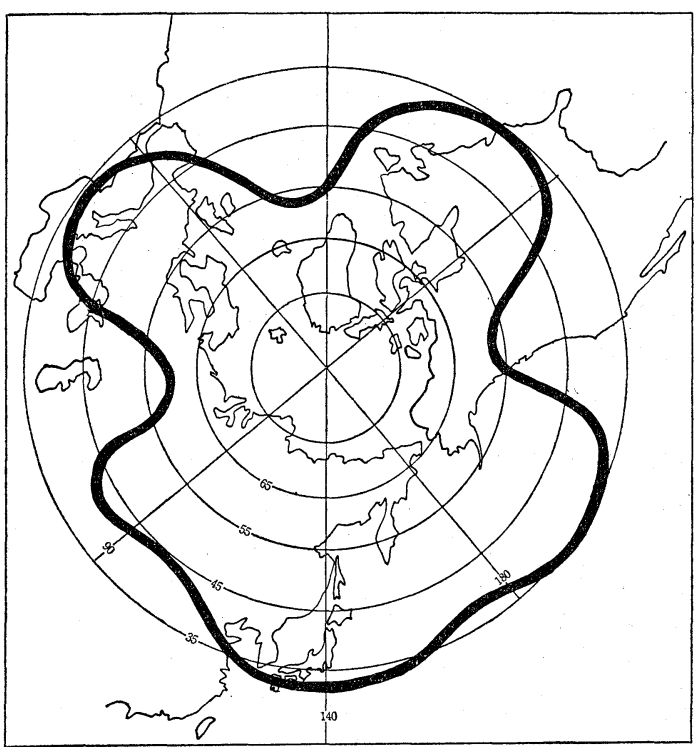

Fig. 1. The circulation of $\mathrm{B}_{2}$ type represented by $18,000 \mathrm{ft}$. contour on $500 \mathrm{mb}$ level map.

The center of circumpolar $18,000 \mathrm{ft}$ contour of $500 \mathrm{mb}$ surface is shifted towards the Pacific Ocean side, where the westerlies are showing high zonal index. This pattern is very similar to La Seur's eccentric circumpolar current pattern shown in his study except a deep trough and a distinct ridge over the North America and Europe.

As stated in the previous paper, strong westerlies show marked meandering near
Rocky Mountains, so that it is presumed that the low index pattern such as the $B_{2}$ type is induced orographically.

The effect of topography is also seen in the flow over Greenland. It is inferred that the circulation of $B_{2}$ type results from the increase of vertical shear of westerlies accompanied by the increase of meridional temperature gradient, and the current is zonal in the Pacific Ocean area while meridional in the North America through Europe due to the influence of topography. The zonal pattern over the Pacific area may be the result of the flatness of the ocean surface.

Three main troughs in the $B_{2}$ type pattern are almost stationary, and the pattern belongs to one of blocking types as mentioned in previous paper. Noted that in other types of blocking troughs are not always so stationary as that of $\mathrm{B}_{2}$ type.

The procedure of selecting the $B_{2}$ pattern from the Northern Hemisphere $500 \mathrm{mb}$ charts

Table 1. The list of days of $\mathrm{B}_{2}$ type circulation during winter seasons of $1944 / 45-1956 / 57$.

\begin{tabular}{l|c|c|c}
\hline & Dec. & Jan. & Feb. \\
\hline $1944 / 45$ & & $1,3,4,5,6,7,8,9$, & \\
& & $10,11,23,25,26,28$ & \\
$1945 / 46$ & & & 9 \\
$1946 / 47$ & & & \\
$1947 / 48$ & & & \\
$1948 / 49$ & & & \\
$1949 / 50$ & & & $12,14,10,11$, \\
$1950 / 51$ & 25 & & \\
$1951 / 52$ & & & \\
$1952 / 53$ & & & \\
$1953 / 54$ & & & \\
$1954 / 55$ & 22,23 & & \\
$1955 / 56$ & & & \\
$1956 / 57$ & $24,25,30,31$ & &
\end{tabular}

is as follows. Taking $18,000 \mathrm{ft}$ contour at $500 \mathrm{mb}$ map in question, check the coincidence of the contour with that of the $\mathrm{B}_{2}$ model. If they roughly agree with each other, the pattern is overlaid on the $B_{2}$ model pattern, and the coincidence of area embraced by $18,000 \mathrm{ft}$ contour, allowing the deviation of $\pm 15 \%$, is the final criterion of the $\mathrm{B}_{2}$ type grouping.

Table 1 shows the dates of the $B_{2}$ type cir- 
culation pattern thus selected. Of all 13 seasons, there were 5 seasons which have no $\mathrm{B}_{2}$ type circulation. The total number of occurrence day is 30 among 1173 day cases.

\section{Temperature anomaly distributions in the case of $B_{2}$ type circulation pattern}

With respect to these 30 cases, the global temperature anomaly distributions were obtained using the data of about one hundred stations in middle latitudes. Selected stations are plotted in Fig. 2, and their names are listed below:

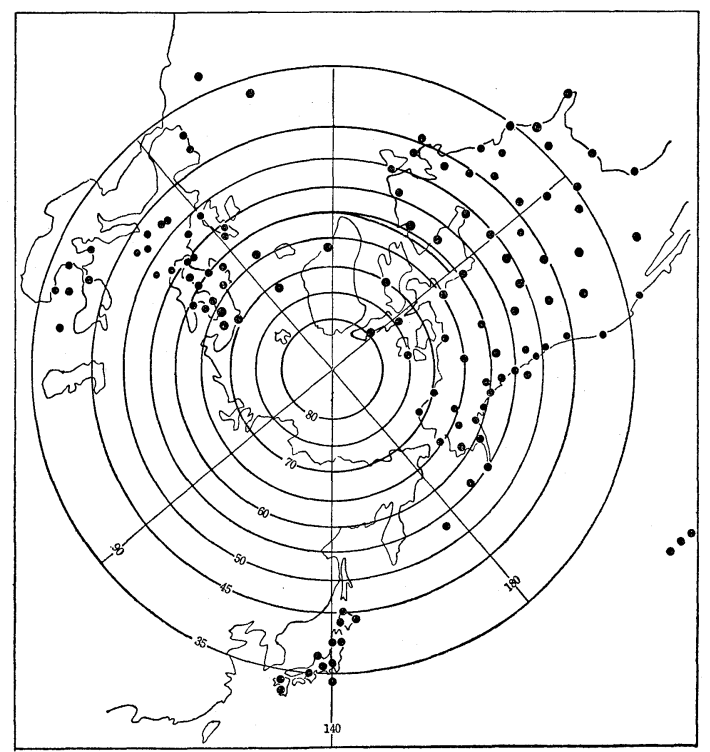

Fig. 2. Meteorological stations.

USA-New York, Caribou, Atlanta, Miami, Hatteras, Charleston, Washington, Little Rock, Chicago, New Orleans, Duluth, St. Louis, Oklahoma City, Rapid City, Brownsville, El Paso, San Diego, San Francisco, Denver, Great Falls, Portland, Salt Lake City ;

Canada-Port Hardy, Sandspit, Prince George, Vancouver, Fort Nelson, Whitehorse, Coppermine, Fort Smith, Norman Wells, Baker Lake, Clyde, Eureka, Resolute, Mould Bay, Edmonton, Regina, Winipeg, Churchill, Armstrong, Moosonee, Tronto, Montreal, Port Harrison, Fort Chimo, Sable Island, Sydney, Gander, Goos Bay;

Alaska-Shemya Island, Cold Bay, Yakutat,
Cordova, Juneau, Annette Island, King Salmon ;

Greenland-Angmagssalik ;

Denmark-Aalborg, K $\phi$ benhavn, Thorshavn;

United Kingdom-Aberdeen, Kew, Eskdalemuir ;

Norway-Oslo, Bergen, Trondheim, Troms $\phi$, Jan Mayen ;

Sweden-Visby, Stockholm, Haparanda ;

Finland-Helsinki, Vasa, Sodankylä ;

Switzerland-Säntis (Mt.), Zürich ;

Austria-Sonnblick (Mt.), Wien ;

Poland-Warszawa, Gdansk (Danzig);

Hungary-Budapest ;

Netherland-DeBilt ;

Greece-Thessaloniki ;

Portugal-Porto, Lisboa, Ponta Delgada (Azores), Funchal (Maderia);

Turkey-Ismir, Ankara, Istanbul, Erzurum, Adana ;

Japan-Wakkanai, Sapporo, Nemuro, Akita, Miyako, Wajima, Matsumoto, Tokyo, Hachijyo, Osaka, Fukuoka, Kagoshima ;

Hawaii-Lihue, Honolulu, Hilo.

Data were published from their respective authorized meteorological offices (ref. Appendix).

These data do not always contain same statistical quantities; especially there are fairy great diversity in daily mean temperature data. For critical standard, the CLINO were used in all cases of temperature and precipitation.

Daily anomaly was constructed as follows: anomaly $=B_{2}$ type occurrence day's mean temperature-CLINO's same monthly mean temperature

Then 30 temperature anomaly maps were constructed. Although anomaly patterns are different to each other some remarkable common features are found, which are shown in Fig. 3 and Fig. 4.

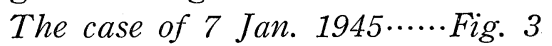

From this flow pattern it is seen that Japan is located at the region where a large trough and lower temperature prevails. In the western part of US, there is a region of considerable high temperature along the Rocky mountains where a ridge exists. In the eastern US, lower temperature area spreads associated with a deep and large trough except southern part where rather higher temper- 


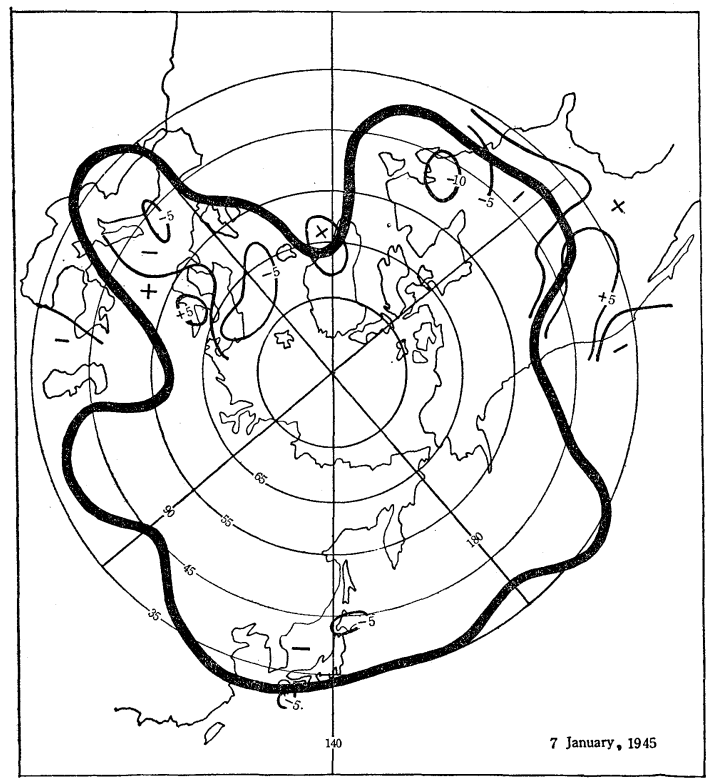

Fig. 3. $18,000 \mathrm{ft}$. contour at $500 \mathrm{mb}$ chart and temperature anomalies on 7 Jan., 1945.

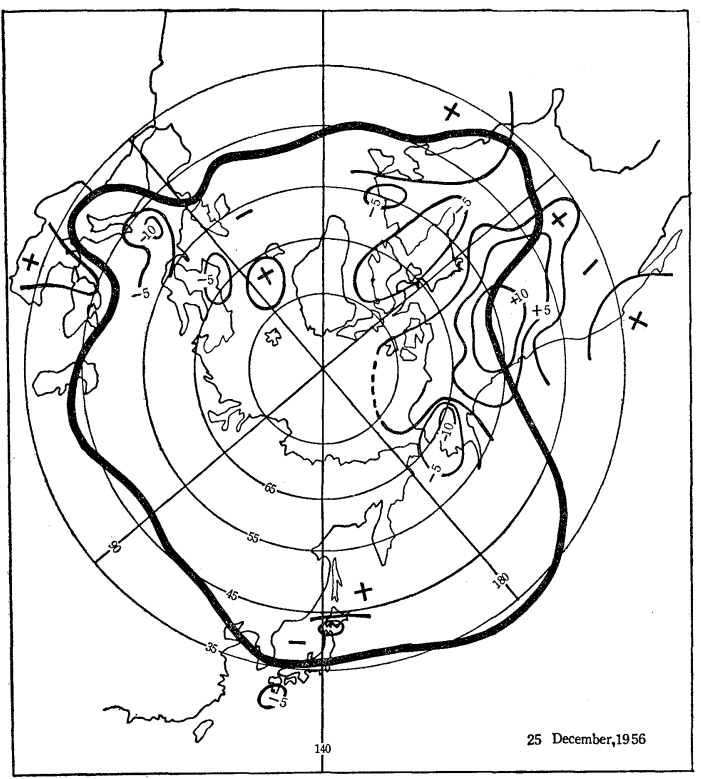

Fig. 4. 18,000 ft. contour at $500 \mathrm{mb}$ level chart and temperature anomalies on 25 Dec., 1956.

ature prevails. In Greenland, higher temperature observed at the top of ridge. In western Europe very cold air bursts into the western half part of its deep trough. Contrary to this situation, there are positive temper- ature anomalies in Turkey and Finland, and these situations correspond to the eastern part of European trough and the ridge of Europe Russia-West Asia.

The case of 25 Dec. 1956….Fig. 4

Severe cold wave attacks Japan, except a part of Hokkaido. In North America, the Rocky mountains area is covered with an air mass of abnormaly high temperature, the value of anomalies being $+15^{\circ} \mathrm{C}$. But there are some colder areas in a part of Alaska, and severe cold weather extends from north to south along the eastern US deep trough. To the east of this trough, several positive temperature anomalies prevailes. In the European trough, abnormal cold wave spreads over. Then several positive anomalies are observed in Turkey and Greece.

These patterns may revel several characteristic foatures on the temperature distribution resulting from $\mathrm{B}_{2}$ type circulation. Namely clear negative anomaly of temperature correspands to trough and clear positive anomaly to ridge, and then cold trough extends to south and warm ridge extends to north.

Marked negative anomalies show $-10^{\circ} \mathrm{C}$ or more and marked positive anomalies show $+10^{\circ} \mathrm{C}$ or more, so their contrasts are very conspicuous where they are same latitudinal stations. These abnormalities are always in North America, and rather less colder regions are seen in West Europe and Far East.

In west Europe, that regime is variable and severe cold wave burst out not always. In Far East, that regime is rather stationary, however, its abnormality is not so strikingly as comparing other two regions.

\section{Precipitation anomaly distributions in the case of $B_{2}$ type circulation pattern}

It is not adequate to use the same estimation method as the case of temperature distribution because a disturbance which brings precipitation is about one tenth magnitude of the planetary wave as $B_{2}$ type circulation model and the local difference of precipitation amount is rather large.

A grouping was used to avoid such difficulty which resulted from these irregurality and locality.

Two sorts of precipitation period are given: Namely one precipitation period is taken out 
as including a previous day of $\mathrm{B}_{2}$ type occurrence and next day, and another one is the case of two days before and two days after. For example, when $\mathrm{B}_{2}$ type were found on 24 and 25 Dec. 1956, one period is from 23 to 26 Dec. 1956, and another one is from 22 to 27 Dec. 1956.

The expected precipitation amount is defined as follows: mean daily precipitation amount (which is mean monthly amount $\div$ number of that month days) $\times$ number of precipitation period days.

To estimate the precipitation distribution the precipitation amount anomaly is grouped to 4 classes and they are-(precipitation amount of the period is below $50 \%$ than the expected precipitation amount of that period), 0 ( $\geqq-50$ $\% \sim \leqq+50 \%$, as samely $),+(>+50 \% \sim \geqq+150$ $\%$, as samely) and $\#(>150 \%$, as samely).

Then precipitation anomaly distributions are analysed for the case of 10 periods, which are 31 Dec. 1944-12 Jan. 1945, 22-29 Jan. 1945, 8-10 Feb. 1947, 24-26 Dec. 1950, 7-15 Feb. 1952, 3-5 Jan. 1953, 5-7 Feb. 1954, 21-24 Dec. 1954, 23-26 Dec. 1956 and 29 Dec. 19561 Jan. 1957.

Fig. 5 shows the estimation of precipitation anomaly by above method on the case of 2326 Dec. 1956. In Japan, there are two distinctive anomaly groups, namely positive anomaly in Japan Sea coast and negative anomaly in Pacific coast, which shows obvious orographic influence for the cold air mass outbreak from Siberia. Clear negative anomalies are found out over the Rocky mountains and the southwestern US and positive anomalies are concentrated in Canadian Pacific coast. In the eastern North America, positive and medium areas are mixed. Alaskan plains have negative anomaly or little precipitation to estimate as well as Canadian Arctic Archipelago. In Europe, there is no clear feature, however, some positive areas are seen along the trough.

There is less clear feature in the mean map which is constructed from 10 case studies. And more conflicted cases are usual in Europe, which means that the flow pattern over there is rather variable than the case of North America or Far East.

The estimation on the case of two days before and two days after for $\mathrm{B}_{2}$ type occurrence day gave same result but with more

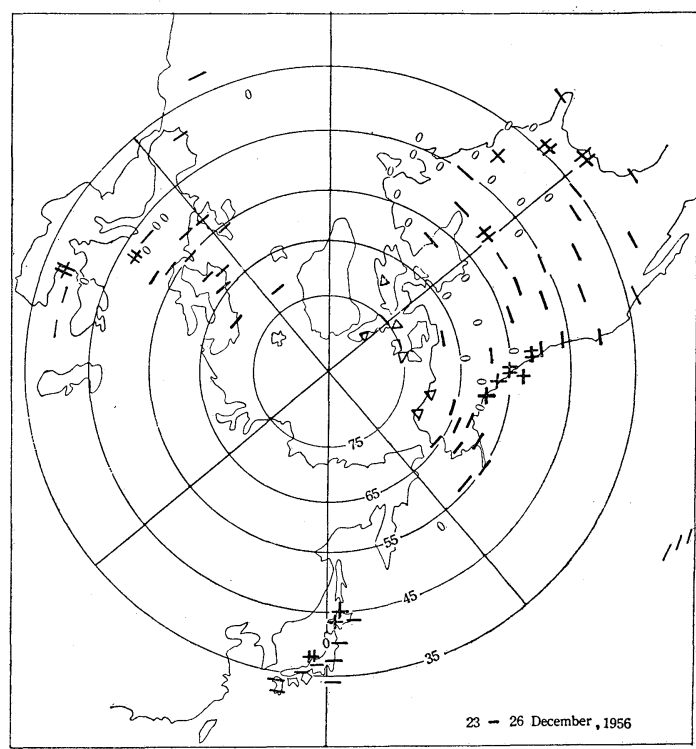

Fig. 5. Precipitation anomalies on 23-26 Dec. 1956 ( $\triangle$ indicates the station whose normal amount is too little to be estimated).

vague pattern.

\section{The meaning of the estimation of $B_{2}$ type circulation}

Daily estimations of $\mathrm{B}_{2}$ type circulation pattern detected a peculiar anomaly distribution on temperature and precipitation, which present an interesting explanation on the problem of Pleistocene glaciation.

From the previous estimations of daily climatic data, the negative temperature anomaly and normal precipitation or rather positive precipitation anomaly are clearly recognized in the region of the eastern North America in the case of $\mathrm{B}_{2}$ type circulation.

Ahlmann's criterion (1948), which pointed out that a certain degree of low temperature needs less precipitation to maintain a glacier regime than the case of higher temperature such as present time, is favourable for a glacial growth in this condition.

In the eastern Locky mountain region, the climatic condition is unfavourable for the large glacial growth as a reason of positive temperature anomaly and negative precipitation anomaly.

These conditions coincide with the evidence that the glacial growth of the eastern Rocky mountain region is less developed one 
than the case of continental glacier of the eastern North America.

The author already presented a working hypothesis in the previous paper (Tsuchiya, 1963), that the $B_{2}$ type circulation in winter is a fundamental circulation which causing to begin the glacial growth. This daily estimation on the case of North America is a positive allowance for that working hypothesis.

In Scandinavia, there is no more positive evidence as the case of North America, however, its rather small scale compared with the North American glaciation suggest that our hypothetical model is a reasonable explanation for the glacial growth.

In Japan, there are lower temperature and heavy snowfall along the Japan Sea coast and lower amount of precipitation along the Pacific coast. That is the characteristic feature associated with the $B_{2}$ type circulation. It is suggested that the period of the Pleistocene glaciation in the mountain areas of Honshu or Hokkaido coincided with that of the other two main glaciations which were clearly observed in the Scandinavian glaciation and the North American glaciation.

It means that several Pleistocene glaciations over the Northern Hemisphere occurred in nearly same period, then their vast continental glacier masses brought a worldwide lower sea level.

Sea level analyses during the Pleistocene period by Fairbridge (1963) and Karstrum (1961) have presented a same phase change between sea level and the glacial growth. Fig. 6 shows the distribution of glaciated area in the Northern Hemisphere during the Pleitocene period by Flint (1949). In this figure two troughs of the $\mathrm{B}_{2}$ type circulation coincide with positions and shapes of the Scandinavian glacier and the North American glacier. We can recognize that the precipitation and temperature anomaly associated with the $\mathrm{B}_{2}$ type circulation is an indicator of the causal condition for the begining of the glacial growth especially in the eastern North America.

Of course it is not the complet explanation of the Pleistocene glaciation but one of possible causes, although there are many nudisolved causes in the glaciation mechanism.

\section{Milankovitch's theory and $B_{2}$ type cir- culation}

Milankovitch's theory is one of plausible explanations of the Pleistocene glaciation, because it is based on earth's astronomical movements that are expressed three components, i.e. eccentricity, equinox and obliquity. He explained that a principal factor is a low insolation in summer, and for the winter situation he thoughts that a warm winter is favourable for heavy snowfall. He did not explain the cause of geographical distribution of the continental glacier.

His computation on the earth's climate based on the value which was presented by an astronomer in his age. Now, some modifications are proposed by a recent investigation (Woerkom, 1953). However they gave no fundamental differences in the time sequence of insolation, so its major variational phase is nearly identified. Woerkom (1953) insisted that Milankovitch's computed temperature is too large, and the temperature resulted from his hypothesis is too small to begin the glacial growth.

However, as in previous author's paper, considering latitudinal difference of insolation change in winter which coincides with Milankovitch's lower summer insolation period, it results into a greater latitudinal temperature gradient, which strength the $d U / d z$ in thermal wind equation. Applicating the Bolin's theory (1950) which hold that a meandering westerly is intensified its meander by the effect of Rocky mountains, we can consider that the $\mathrm{B}_{2}$ type circulation is a result of strengthening $d U / d z$.

In winter, the $\mathrm{B}_{2}$ type circulation brings lower temperature and moderate or rather heavy precipitation (usually it means snowfall) into certain regions as previously mentioned. In the same time, over other certain regions where ridge pressure pattern dominates, higher temperature and lower precipitation amount prevailes.

These temperature and precipitation anomaly patterns are fitted to the Pleistocene glaciation map as seeing in Fig. 6. Namely, Milankovitch's theory consists with our general circulation mechanism.

Another explanation is possible for the 


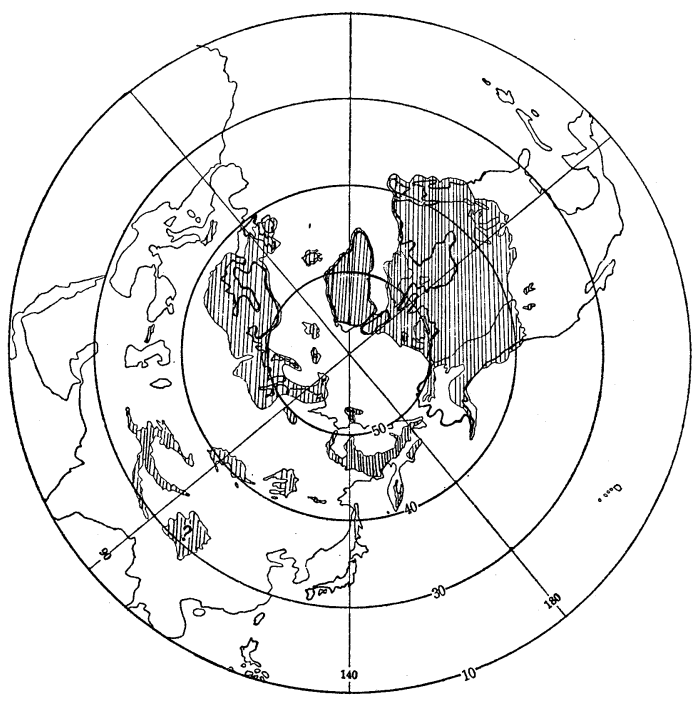

Fig. 6. Glaciated area during Pleistocene (from Flint).

reason of secular latitudinal insolation change. In summer, his diagram shows a decrease of insolation over the high latitude, which is more clear than the case of middle or low latitude when his insolation curve is glacial stage. Then a latitudinal insolation gradient becomes larger, which means such summer condition resembles to winter condition. In this case, the $d U / d z$ will be increase like winter. Finally, the condition that Milankovitch had proposed is favourable for the glacial growth. And as mentioned in the previous paper (Tsuchiya 1963), the global orographical distribution influenced on the distribution of the continental glacier such as the Scandinavian and North American glacier during the Pleistocene period.

One of weak points in the Milankovitch's theory is the degree of decreasing temperature which extending as $5^{\circ} \mathrm{C}$, however, as the author's proposal, there are several regions which rising or lowering temperatures for respectively, then it needs not so large global decreasing temperature as he said, because the continental glaciers developed over the regions where especially colder climate prevales over than the other regions.

\section{Abnormal thickness anomaly from Aug. to Oct. 1962}

We had abnormal climate in winter of 1962/
63 , and its reasonable cause is still unexplained. The winter of $1962 / 63$ was a sort of the $\mathrm{B}_{2}$ type circulation. The author presents a causal condition to begin the $B_{2}$ type circulation, which is a increasing latitudinal temperature gradient. So we can expect an increasing of latitudinal temperature gradient in front of the winter of $1962 / 63$. Fig. 7 shows the average three months $1000-700 \mathrm{mb}$ thickness anomaly during Aug.-Oct. 1962. An abnormal positive anomaly in the middle latitude and negative anomaly in the high latitude is an indicator of abnormally large latitudinal temperature gradient in troposphere.

This abnormality changed in November, and

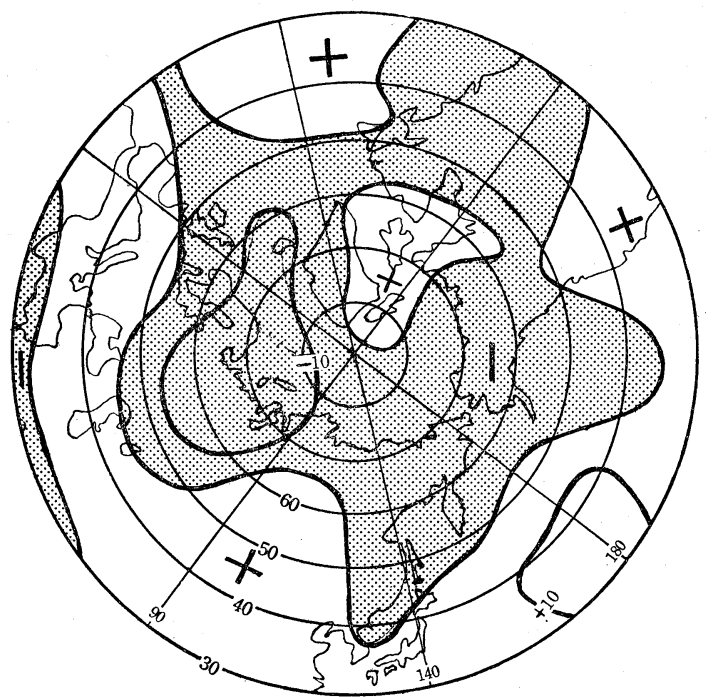

Fig. 7. $1000-700 \mathrm{mb}$ thickness anomaly pattern (unit : $10 \mathrm{ft}$.) averaged from Aug. to Oct., 1962.

reversal gradient developed in December, then severe cold wave burst out in the several regions; eastern North America, western Europe and Far East.

This phenomenon suggests a close relationship between abnormality in the winter of 1962/63 and thickness abnormality during Aug.-Oct. 1962. Although we have few data to analyze this phenomenon, some suggestions are still possible. Namely, it is a probable explanation that increasing latitudinal temperature gradient which resulted from an accumlation of heat in the middle latitude and a decreasing in the high latitude is a favourable situation for the begining of the $B_{2}$ type 
circulation.

Of course, there are some differences in the relationship between this continuous phenomenon and the $\mathrm{B}_{2}$ type circulation which is delivered from thermal wind equation in the previous paper (Tsuchiya, 1963), but their resemble natures may support above explanation.

\section{Conclusion}

It may be a slightly bold attempt to explain the mechanism of climatic fluctuation which existed some ten thousand years ago such as in the Pleistocene glaciations, using the information obtained from the general circulation patterns at present. One of the conclusions of this study is that a special type of circulation $\left(\mathrm{B}_{2}\right.$ type), which appears not frequently but not so unusually, might be a fundamental cause for the climatic anomalies in the several regions on the globe, such as the western Europe, the eastern North America and the vicinity of Japan. And if these anomalies persist for long years, it is possible to induce the glacial growth in such regions.

It can therefore be said that the external influences such as the solar variation and the internal effects such as volcanic dusts or $\mathrm{CO}_{2}$ in the atmosphere are not always needed to explain the development or the retreat of the glaciers.

Milankovitch presented the basic equation for the accumulated amount of insolation recieved by the earth's surface, and he computed the insolation as a function of latitude and season over one million years. Then he found out that there exist certain periods during which the intensity of summer insolation appears to be extremely low in middle and high latitudes. This is his famous glacial growth theory.

The author analyzed the case of winter circulation which corresponds to his lower summer insolation period. Obviously, however, the present time does not belong to such a period, so that the author presented a model which is derived from Bolin's theory (Bolin, 1950). Then it was shown that the $\mathrm{B}_{2}$ type circulation can be formed when the latitudinal gradient of insolation intensity in winter is large. At present, the circulation of this type does not occur so frequently, because the atmosphere is not in the lower summer insolation period nor in higher winter insolation period.

In the case of $\mathrm{B}_{2}$ type circulation, we may find out some characteristic features; (1) there are several groups of temperature and precipitation anomalies in the longitudinal direction, (2) an exceptionally cold region exists in the western Europe, and (3) the eastern North America is covered with a vast air mass of low temperature. These features suggest some relations between the $B_{2}$ type circulation and the Pleistocene glaciation.

On the other hand, it is speculated that, when the latitudinal temperature gradient is large, one can expect the occurrence of the $\mathrm{B}_{2}$ type circulation. For example, in winter of 1962/63, an abnormal circulation which resembles the $B_{2}$ type circulation persisted, and in the foregoing season there was an abnormal heating in the middle latitude. This situation perhaps had a strong meridional circulation during the following winter season, as a result of strong temperature gradient from middle to high latitude in the troposphere.

In consequence of above discussions, the author presents the $B_{2}$ type circulation as a fundamental model which explains the glacial growth during the Pleistocene as well as abnormally cold wave pattern at the present time.

This hypothesis does not contradict to the Simpson's proposal $(1934,1957,1959)$ in the point that he intended to explain the glacial growth in terms of the general circulation, except that he introduced a fantastastic solar variaton in his model. Our theory is also compatible with that of Milankovitch.

As was pointed out by Fairbridge (1963), however, there are considerable time lags between the real glacial phase and that suggested by Milankovitch in his catalogue for the reason of heat capacity of ice and water and other factors such as the change of albedo of the earth surface. There remain, of course, many unsolved problems.

\section{Acknowledgement}

The author wishes to express his thanks to Dr. S. Sakuraba for his stimulative sugges- 
tion and helpfull advice to this manuscript. The author also whishes to express his appreciation to the following members of Climatological Association: Prof. E. Fukui, Assis. Prof. T. Sekiguti, Dr. M. Yoshino and Dr. T. Asai for their helpfull discussion on this subject.

\section{References}

Ahlmann, H. W., 1948: in "Derbyshire, E., : Glaciation and subsequent climatic changes in central Quebec-Labrador: a critical review. Geogr. Ann., 17, 49-61, 1960"

Bolin, B., 1950: On the influence of the earth's orography on the general charactor of the westeries. Tellus, 2, 184-195.

Fairbridge, R.W., 1961: Mean sea level related to solar radiation during the last 20,000 years. in "Changes of Climate-Proc. Rome Symposium organized by UNESCO and WMO. Arid zone research 20, Pub. 1963 " pp. 229-242.

Flint, R.F., 1949: Glacial geology and the Pleistocene epoch. $589 \mathrm{p}$.

Flohn, H., 1961a: Man's activity as a factor in climatic change. Ann. N. Y. Acad. Sci., 95, 1, 271-281.

- 1961b: Theories of climatic change from the viewpoint of the global energy budget. in "Changes of Climate-Proc. Rome Symposium organized by UNESCO and WMO. Arid zone research 20, Pub. 1963 " pp. 339-344.

Karlstrom, T., 1961 : The glacial history of Alaska: its bearing on paleoclimatic theory. Ann. N.Y. Acad. Sci., 95, 1, 290-340.

Kraus, E.B., 1960: Synoptic and dynamic aspects of climatic change. Quart. J. Roy. meteor. Soc., 86, 1-15.

Lamb, H.H. and A.I, Johnson 1959: Climatic variation and observed changes in the general circulation. Pt. I-II. Geogr. Ann., 41 94-134. 1961 : Loc. cit, Pt. III, ibid., 43, 363-400.

La Seur, N.E., 1954: On the asymmetry of the middle-latitude circum-polar current. $J$. Meteor., 11, 34-57.

Milankovitch, M., 1930: Astronomische Theorie der Kimaschwankungen. in "Handbuch der Klimatologie” (Köppen-Geiger ed.), Bd. I, A, pp. 118-176.

Simpson, G. C., 1934: World climate during the Quaternary period. Quart. J. Roy. meteor. Soc., 60, 425-478.

— 1957 : Further studies in world climate. ibid., 83, 459-485.

, 1959: World temperatures during the Pleistocene. ibid., 85, 332-349.

Tsuchiya, I., 1963: An analysis on the relationship between general circulation and climatic fluctuation.

Pt. 1. General circulation model leading to climatic fluctuation. J. meteor. Soc., Japan, Ser. II, 41, 288-298.

Willet, H.C., 1949: Long-period fluctuations of the general circulation of the atmosphere. $J$. Meteor., 6, 34-50.

Woerkom, A. J. J. van, 1953: The astronomical theory of climatic changes in "Climatic changes" (Shapley, H. ed.) pp. 147-157.

\section{APPENDIX}

Data Sources.

U.K. Met. Office: The observatories year book

Zentralanstalt f. Met. Geodynamik, Österrich : Jahrbücher der Zentralanstalt f. Met. Geodynamik

Państwowy Instytut Hydrolo.-Met., (Poland): Rocznik Met.

Országos Met. Intézet (Hungary): Ann. de l'Inst. Central de Mét.

Finnish Met. Office: Met. Yearbook of Finland

Det Norsk Met. Inst.: Norsk Met. Årbok

Sveriges Met. Hydro. Inst. : Met. Obs. in Sweden

Det. Danske Met. Inst. : Met. Årbog

Koninklijk Nederlands Met. Inst.: Jaarboek A (Met.)

Schweizerischen Met. Zentralanstalt.: Annalen der Schweizerischen Met. Zentralanstalt

Univ. Thessaloniki, Met. Inst. (Greece): Ann. de l'Institut Mét. Climat.

Turkish State Met. Service: Yillik Met. Bülteni

Japan Met. Agency: Monthly Report of the Japan Met. Agency

Met. Branch (Canada): Monthly Record of Met. Obs. in Canada

US Weather Bureau: Climatological Data (by sections)

- Monthly Weather Review

WMO : CLINO 1931-1960

“Synoptic N. Hemisphere Weather Map Series" are :

US Weather Bureau : Daily series synoptic weather maps, N. Hemisphere sea level and $500 \mathrm{mb}$ charts, 1944. 12-1945. 9

US AAF Air Weather Service: N. Hemisphere historical weather maps, sea level and $500 \mathrm{mb}$, 1945. 10-1948. 12

US Weather Bureau : Daily series synoptic weather maps, N. Hemisphere sea level and $500 \mathrm{mb}$ charts with synoptic data tabulation, 1949. 11951. 12

-: Daily series synoptic weather maps, $\mathrm{Pt}$. $1, \mathrm{~N}$. Hemisphere sea level and $500 \mathrm{mb}$ charts, 1952. 1-

Vol. 42, No. 5, 1964 


\section{大循環と気候変動との関係に関する解析（第 2 報）}

一特別な循環型 $\left(\mathrm{B}_{2}\right.$ 型）の日別評価と議論 —

土屋巌

気象序

第 1 報で提案した $\mathrm{B}_{2}$ 型（定常トラフの顕著なブロッキング型）循環を，1944 年 12 月〜1957 年 2 月の 13 の冬季 節から一定の規準のもと飞選び出し，選出された 30 例とついて，その気候特性を調べた。北半球中緯度の約 100 地 点の気象日表によって顕著な気温と降水の偏差傾向が米国東部や西ヨーロッパ拉よび日本などに見出された。この偏 差の型は洪積世水河期の大陸氷河の特殊な分布型を暗示させるものである。

従って，第 1 報に提案したミランコピッチの仮説の適用は $\mathrm{B}_{2}$ 型循環を媒介として支持される結果となる。 終りに 1962/63 年の異常な世界的寒波と対する簡単な考察を加え， $\mathrm{B}_{2}$ 型発現の条件の 1 例証を示した。 